\title{
Irinotecan Every 21 Days Regimen
}

National Cancer Institute

\section{Source}

National Cancer Institute. Irinotecan Every 21 Days Regimen. NCI Thesaurus. Code

C160069.

A chemotherapy regimen consisting of irinotecan every 21 days that may be used in the treatment of colorectal cancer. 